\title{
MOTIVASI, PEMAHAMAN AKUNTANSI DAN MINAT MAHASISWA UNTUK MENGIKUTI SERTIFIKASI AKUNTAN PROFESIONAL
}

\author{
MOTIVATION, ACCEPTANCE OF ACCOUNTING AND STUDENTS \\ 'INTEREST TO FOLLOW PROFESSIONAL ACCOUNTANT CERTIFICATION
}

\author{
Franciska Diva Setiani' ${ }^{1}$, Maria Rio Rita ${ }^{2)}$ \\ ${ }^{1,2)}$ Fakultas Ekonomika dan Bisnis. Universitas Kristen Satya Wacana \\ J1. Diponegoro No.52-60, Salatiga, Kec. Sidorejo, Kota Salatiga, Jawa Tengah 50711 \\ 232016022@student.uksw.edu,maria.rita@uksw.edu
}

\begin{abstract}
ABSTRAK
Sertifikasi akuntan profesional merupakan salah satu cara agar mahasiswa akuntansi nantinya dapat diakui sebagai akuntan profesional. Sayangnya, tidak semua mahasiswa akuntansi tertarik mengikuti sertifikasi akuntan profesional. Penelitian ini bertujuan untuk mengetahui apakah motivasi ekonomi, motivasi sarjana, motivasi kualitas dan pemahaman akuntansi berpengaruh terhadap minat mahasiswa akuntansi mengambil sertifikasi profesi akuntan. Dalam penelitian ini menggunakan data primer yang diperoleh melalui penyebaran kuisioner secara langsung maupun melalui e-mail mahasiswa kepada mahasiswa akuntansi Universitas Kristen Satya Wacana (UKSW). Penelitian ini menggunakan purposive sampling. Teknik analisis data yang digunakan adalah analisis regresi logistik biner. Hasil penelitian menunjukkan bahwa tingkat motivasi berpengaruh terhadap minat mahasiswa akuntansi mengikuti sertifikasi akuntan profesional. Sedangkan motivasi ekonomi, motivasi kualitas dan pemahaman akuntansi tidak berpengaruh terhadap minat mahasiswa akuntansi untuk mengikuti sertifikasi profesi akuntan.
\end{abstract}

Kata Kunci: Sertifikasi Profesi Akuntan, Motivasi Ekonomi, Motivasi Gelar, Motivasi Kualitas, Pemahaman Akuntansi

\section{ABSTRACT}

Professional accountant certification is one way that accounting students can later be recognized as professional accountants. Unfortunately, not all accounting students are interested in joining professional accountant certification. This study aims to determine whether economic motivation, degree motivation, quality motivation and understanding of accounting affect the interest of accounting students to take professional accountant certification. In this study uses primary data, which were obtained through questionnaires distributed directly and also through student e-mails to the accounting students at Satya Wacana Christian University (SWCU). This research uses purposive sampling. The data analysis technique used is binary logistic regression analysis. The results showed that degree motivation effect the interest of accounting students to take professional accountant certification. Meanwhile, economic motivation, quality motivation and understanding of accounting do not effect on interest of accounting students to take professional accountant certification.

Keyword(s): Professional accountant certification, Economic motivation, Degree motivation, Quality motivation, Understanding of accounting

\section{PENDAHULUAN}

Profesi akuntan sangat dibutuhkan demi terwujudnya tranparasi informasi keuangan yang berkualitas dan dapat dipercaya. Dengan diresmikannya MEA
(Masyarakat Ekonomi ASEAN) pada tahun 2015 dan juga kemajuan teknologi informasi yang sangat pesat, khususnya di Indonesia, menimbulkan tuntutan profesionalisme bagi calon akuntan untuk selalu mengembangkan 


\section{SEGMEN Jurnal Manajemen dan Bisnis}

Volume 17 No 1 Januari 2021

p-ISSN: 0216-938X e-ISSN: 2684-8414

kemampuannya terutama di bidang akuntansi. Tuntutan ini semakin menguat di era MEA ini, karena bukan hanya barang dari luar negeri saja yang masuk ke Indonesia, tetapi juga tenaga kerja profesional. Selain itu, pekerjaan akuntansi merupakan pekerjaan yang sangat mungkin untuk digantikan oleh artificial intelligence (kecerdasan buatan), seperti contohnya robot atau software. Oleh karena itu sebagai calon akuntan, lebih baik jika mahasiswa selalu berusaha untuk meningkatkan kemampuan profesional dan kreativitasnya (Sidik, 2019).

Sertifikasi akuntan profesional merupakan salah satu cara agar dapat diakui sebagai akuntan yang profesional. Namun sayangnya, tidak semua calon akuntan dibekali oleh sertifikasi akuntan profesional. Berdasarkan data dari Ikatan Akuntansi Indonesia (IAI), jumlah mahasiswa akuntansi di Indonesia pada tahun 2016 tercatat lebih dari 265.000 mahasiswa aktif yang berasal dari 589 perguruan tinggi di seluruh Indonesia (IAI, 2016). World Bank juga menyatakan bahwa rata-rata jumlah lulusan mahasiswa akuntansi dari seluruh negara ASEAN tiap tahunnya berjumlah 77.330 orang. Sedangkan di Indonesia rata-rata lulusan akuntansi setiap tahunnya adalah 35.000 orang, yang berarti hampir 50\% lulusan akuntansi di ASEAN berasal dari Indonesia. Namun sayangnya, jumlah lulusan yang besar tersebut tidak diimbangi dengan jumlah akuntan profesional. Tercatat hanya 24.000 orang atau sekitar $68 \%$ saja di Indonesia yang terdaftar sebagai akuntan profesional di IAI (Ikatan Akuntansi Indonesia) (Afrianto, 2016). Bahkan Setyawan \& Iswanaji (2019) menyatakan bahwa Indonesia, memiliki jumlah akuntan profesional yang relatif sedikit dibandingkan negara ASEAN lain, meskipun memiliki lulusan akuntansi dalam jumlah yang besar. Hal ini dikhawatirkan dapat menjadi ancaman bagi Indonesia, karena berdasarkan Mutual Recognition Arrangements (MRA) negaranegara di ASEAN, terdapat delapan profesi yang dibutuhkan pada era perdagangan bebas (Masyarakat Ekonomi ASEAN/MEA) ini, salah satunya yaitu profesi di bidang akuntansi.

Penelitian sebelumnya tentang niat untuk mengambil sertifikasi akuntan dengan pengujian theory of planned behavior dan teori motivasi oleh Dewi, Putri, \& Dewi (2018) membuktikan bahwa, sikap, norma subjektif, pemahaman, motivasi karir, dan motivasi prestasi berpengaruh terhadap niat mahasiswa mengikuti sertifikasi akuntan profesional Association of Chartered Certified Accountant (ACCA), Chartered Accountant (CA) dan Certified Public Accountant (CPA), sedangkan untuk kontrol perilaku persepsian dan motivasi ekonomi tidak berpengaruh. Penelitian selanjutnya tentang pengaruh motivasi akuntan terhadap minat untuk memperoleh gelar CA di wilayah Yogyakarta oleh Setyawan \& Iswanaji (2019) menunjukkan bahwa motivasi kualitas, motivasi sosial berpengaruh positif pada minat akuntan untuk memperoleh gelar CA, sedangkan motivasi karir dan motivasi ekonomi tidak berpengaruh signifikan.

Pada penelitian ini, beberapa dimensi motivasi menjadi variabel yang diduga mempengaruhi minat mahasiswa untuk mengikuti sertifikasi akuntan profesional, karena motivasi merupakan salah satu daya penggerak atau daya upaya dalam diri seseorang untuk melakukan aktivitas tertentu demi mencapai tujuan tertentu (Sadirman, 1986; 73). Selain itu ditambahkan juga variabel pemahaman tentang akuntansi sebagai salah satu yang mempengaruhi minat mengikuti sertifikasi akuntan profesional. Variabel pemehaman akuntansi ditambahkan karena berdasarkan hasil penelitian, seperti 


\section{SEGMEN Jurnal Manajemen dan Bisnis}

Volume 17 No 1 Januari 2021

p-ISSN: 0216-938X e-ISSN: 2684-8414

pada penelitian Yulaini (2018) yang menyatakan bahwa salah satu faktor internal yang mempengaruhi minat adalah pemahaman. Penelitian ini khususnya ingin membahas mengenai minat mahasiswa untuk mengikuti sertifikasi akuntan profesional, karena pada penelitian sebelumnya sangat jarang yang meneliti tentang sertifikasi akuntan profesional.

Melihat rendahnya minat mahasiswa akuntansi untuk meningkatkan kemampuan profesionalnya ditengah semakin besarnya tuntutan profesionalisme, penulis terdorong untuk meneliti faktor yang berpengaruh dengan minat mahasiswa akuntansi untuk mengikuti ujian sertifikasi akuntan profesional. Selain itu juga, masih relatif sedikit penelitian yang membahas tentang sertifikasi akuntan profesional karena penelitian sebelumnya sebagian besar fokus pada Pendidikan Profesi Akuntansi (PPAk). Dari persoalan penelitian yang sudah dijelaskan sebelumnya, maka muncul pertanyaan penelitian yaitu dapat dirumuskan sebagai berikut:

Bagaimana pengaruh motivasi ekonomi, motivasi gelar, motivasi kualitas, dan pemahaman akuntansi terhadap minat mahasiswa akuntansi Fakultas Ekonomika dan Bisnis di Universitas Kristen Satya Wacana (FEB UKSW) untuk mengikuti sertifikasi akuntan profesional?

Tujuan studi ini adalah meneliti pengaruh motivasi, pemahaman akuntansi, terhadap minat mahasiswa FEB UKSW untuk mengikuti ujian sertifikasi akuntan profesional. Hasil studi ini diharapkan dapat bermanfaat bagi pihak universitas (khususnya UKSW) agar dapat meningkatkan minat mahasiswa untuk mengikuti sertifikasi akuntan profesional, sehingga dapat menciptakan mahasiswa lulusan akuntansi yang kompeten dan profesional untuk menghadapi persaingan di era MEA. Bagi pihak mahasiswa, penelitian ini diharapkan dapat meningkatkan kesadaran mahasiswa untuk dapat meningkatkan kompetensinya sebagai calon akuntan di era global ini dan juga penelitian ini diharapkan dapat menyumbang riset khususnya di bidang akuntansi.

\section{THEORY OF REASONED ACTION}

Theory of Reasoned Action (TRA) merupakan hasil pengembangan penelitianpenelitian sebelumnya yang dimulai dari teori sebelumnya yaitu teori sikap (Theory of Attitude). Jogiyanto (2007, 25-26) menyatakan bahwa dalam teori ini dijelaskan suatu perilaku dilakukan karena individu mempunyai intensi atau minat untuk berperilaku. Tujuan dan manfaat teori ini adalah antara lain untuk meramalkan dan memahami pengaruh motivasional terhadap perilaku yang sepenuhnya atas dorongan individu itu sendiri.

Mihartinah \& Corynata (2018), menyatakan bahwa perilaku secara penuh di bawah kendali individu. Dalam TRA terdapat 2 (dua) faktor yang mempengaruhi perilaku, yaitu sikap terhadap perilaku dan norma subjektif. Berikut adalah model dari TRA:

Menurut Ajzen (2005), faktor-faktor yang mempengaruhi perilaku berdasarkan TRA adalah sikap terhadap perilaku dan norma subyektif. Faktor pertama yaitu sikap terhadap perilaku, merupakan hasil evaluasi positif atau negatif individu terhadap perilaku yang akan dilakukan. Sikap terhadap perilaku ini ditentukan oleh behavioral belief yang merupakan keyakinan yang didapatkan mengenai konsekuensi atas suatu perilaku. 


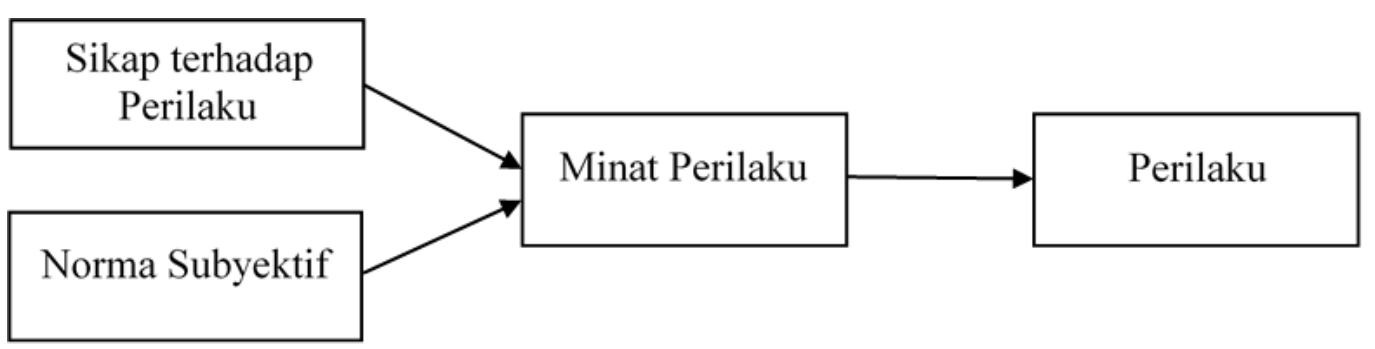

Gambar 1. Model TRA

Sumber: Jogiyanto $(2007,35)$

Belief berkaitan dengan penilaian subjektif individu tentang dunia sekitarnya, pemahaman mengenai diri sendiri dan juga lingkungannya. Faktor yang kedua, norma subyektif adalah pandangan atau persepsi individu terhadap tekanan orang lain atau kepercayaan orang lain, yang mempengaruhi niat untuk melakukan atau tidak suatu perilaku yang sedang dipertimbangkan. Faktor ini, berkaitan dengan kepercayaan individu terhadap individu atau kelompok lain yang akan menyetujui atau tidak menyetujui, mendukung atau tidak mendukung perilaku yang akan dilakukan.

Sebenarnya sudah ada pengembangan dari TRA ini yaitu Theory of Planned Behavior (TPB), dengan penambahan satu faktor lagi yang mempengaruhi perilaku yaitu kontrol perilaku persepsian. Pada TPB perilaku individu atau kelompok tidak secara penuh di bawah kendali individu atau kelompok itu sendiri (Mihartinah \& Coryanata, 2018). Alasan penelitian ini menggunakan TRA karena dalam penelitian ini variabel-variabel yang mempengaruhi minat mengikuti sertifikasi akuntan profesional yaitu motivasi dan pemahaman akuntansi merupakan dorongan dari individu itu sendiri.

\section{MOTIVASI}

Motivasi atau motif dapat diartikan sebagai daya upaya atau daya penggerak yang mendorong seseorang untuk melakukan aktivitas-aktivitas tertentu demi mencapai suatu tujuan (Sadirman, 1986). Menurut Uno $(2012,3)$ motivasi adalah suatu dorongan dari dalam diri seseorang, untuk melakukan perilaku lebih baik dari sebelumnya dalam rangka memenuhi kebutuhannya. Dapat disimpulkan, motivasi adalah daya penggerak dalam diri seseorang untuk melakukan perilaku yang lebih baik dari sebelumnya untuk mencapai suatu tujuan.

Sertifikasi akuntan profesional penting agar nantinya calon akuntan maupun akuntan dapat memiliki daya saing untuk menghadapi era MEA. Diperlukan motivasi dari dalam diri mahasiswa agar memiliki minat mengikuti sertifikasi. Ada beberapa macam dimensi dari motivasi, seperti ekonomi, karir, gelar, kualitas, dan lain sebagainya.

Sapitri \& Yaya (2015) menjelaskan bahwa motivasi ekonomi adalah dorongan dari dalam diri seseorang untuk meningkatkan kemampuan pribadinya dengan tujuan untuk mencapai penghargaan finansial atau penghargaan ekonomi yang diinginkannya. Penghargaan ekonomi sendiri dapat berupa penghargaan langsung seperti gaji, upah atau bonus dan juga penghargaan tidak langsung berupa tunjangan, program pensiun atau manfaat lainnya. Motivasi gelar dimaknai Sari, Andini, \& Paramita (2017) sebagai dorongan dalam diri seseorang untuk mendapatkan gelar tertentu yang akan meningkatkan status sosial dan mempermudah mencari pekerjaan. Nisa (2012), mendefinisikan motivasi karir sebagai 


\section{SEGMEN Jurnal Manajemen dan Bisnis}

Volume 17 No 1 Januari 2021

p-ISSN: 0216-938X e-ISSN: 2684-8414

dorongan dari dalam diri seseorang untuk meningkatkan kemampuan pribadinya dalam rangka mendapatkan karir yang lebih baik dari sebelumnya. Terakhir adalah motivasi kualitas, Setyawan \& Iswanaji (2019) mendefinisikan sebagai dorongan dari dalam diri seseorang untuk meningkatkan kualitas diri dalam hal kemampuan profesionalnya.

Dalam penelitian ini, peneliti tidak meneliti semua dimensi motivasi yang ada. Fokus penelitian ini adalah pada dimensi motivasi yang sudah diuraikan di atas yaitu motivasi ekonomi, motivasi gelar, dan motivasi kualitas. Hal ini dikarenakan, Setyawan \& Iswanaji (2019) membuktikan bahwa motivasi karir tidak berpengaruh signifikan terhadap minat memperoleh gelar CA yang merupakan salah satu jenis sertifikasi akuntan profesional. Selain itu karena responden dalam penelitian merupakan mahasiswa strata satu yang belum memiliki jenjang karir dalam pekerjaan sebelumnya, maka kurang cocok jika menggunakan variabel motivasi karir.

\section{PEMAHAMAN AKUNTANSI}

Pemahaman berasal dari kata paham yang memiliki arti dalam Kamus Besar Bahasa Indonesia (KBBI) sebagai pandai atau mengerti benar. Sedangkan untuk definisi akuntansi menurut Sari \& Prastiti (2016) merupakan sebuah sistem informasi keuangan mengenai aktifitas ekonomi dan kondisi suatu perusahaan, untuk menghasilkan output berupa laporan keuangan yang nantinya akan dikomunikasikan kepada para pemangku kepentingan dalam suatu perusahaan sebagai dasar pengambilan keputusan. Dapat disimpulkan, pemahaman akuntansi adalah kondisi atau keadaan saat seseorang memiliki kemampuan atau mengerti benar-benar suatu sistem informasi keuangan mengenai aktifitas ekonomi dan kondisi suatu perusahaan, untuk menghasilkan output berupa laporan keuangan yang nantinya akan digunakan sebagai dasar pengambilan keputusan para pemangku kepentingan dalam suatu perusahaan.

\section{MINAT}

Jogiyanto (2007, 25) menyatakan bahwa minat atau intensi merupakan keinginan untuk melakukan suatu perilaku tertentu. Perilaku (behavior) adalah kegiatan atau tindakan yang nyata telah dilakukan seseorang. Sedangkan menurut Siagian (2015) minat dapat diartikan sebagai rasa suka atau ketertarikan dalam diri seseorang terhadap suatu hal atau aktivitas tertentu. Dapat disimpulkan, minat adalah keinginan atau ketertarikan individu untuk melakukan kegiatan atau aktivitas tertentu.

Dalam penelitian ini yang dimaksud dengan minat adalah keinginan dari seseorang atau mahasiswa untuk mengikuti sertifikasi akuntan profesional. Penelitian ini meneliti faktor motivasi dan pemahaman akuntansi sebagai faktor yang diduga dapat mempengaruhi minat mahasiswa untuk mengikuti sertifikasi akuntan profesional.

\section{SERTIFIKASI AKUNTAN PROFESIONAL}

Sertifikasi menurut Mulyasa (2009; 33 34), prosedur yang digunakan oleh pihak yang berwenang untuk mengungkapkan atau memberikan jaminan tertulis bahwa seseorang telah menguasai kompetensi dalam bidang tertentu. Profesional adalah pekerjaan atau kegiatan yang dilakukan seseorang dan menjadi sumber penghasilan yang memerlukan keahlian, kemahiran, atau kecakapan yang memenuhi standar mutu atau norma tertentu serta memerlukan pendidikan profesi (Undang-undang Republik Indonesia 


\section{SEGMEN Jurnal Manajemen dan Bisnis}

Volume 17 No 1 Januari 2021

p-ISSN: 0216-938X e-ISSN: 2684-8414

nomor 14 tahun 2005 pasal 1 ayat 4 tentang Guru dan Dosen, 2005).

Dapat disimpulkan bahwa sertifikasi akuntan profesional adalah prosedur pemberian sertifikat kompetensi kepada seseorang yang memiliki keahlian, kemahiran, atau kecakapan di bidang akuntansi yang memenuhi standar mutu atau norma tertentu. Terdapat beberapa jenis sertifikasi akuntan profesional yang ada di Indonesia, berikut beberapa contohnya:

\section{Certified Public Accountant (CPA)}

Institut Akuntan Publik Indonesia (IAPI) menyatakan bahwa CPA merupakan sertifikasi berbasis kompetesi individu yang dibutuhkan untuk berpraktek atau keahlian yang dibutuhkan untuk profesi akuntan publik (Ikatan Akuntan Publik Indonesia, 2016). CPA merupakan sertifikasi tertinggi profesi akuntan publik di Indonesia.

2. Chartered Accountant (CA)

Menurut Mihartinah \& Coryanata (2018), CA merupakan salah satu jenis sertifikasi yang dikeluarkan oleh IAI sebagai kualifikasi akuntan profesional yang diakui secara internasional dan sesuai dengan panduan standar internasional.

3. Certified Professional Management Accountant (CPMA)

CPMA adalah sertifikasi akuntan profesional khususnya dibidang akuntansi manajemen yang hanya berlaku di Indonesia, karena CPMA ini diterbitkan oleh Institut Akuntan Manajemen Indonesia (IAMI) (Sari, 2016).

4. Sertifikasi Konsultan Pajak

Sertifikasi Konsultan Pajak adalah kegiatan untuk memperoleh surat keterangan keahlian sebagai konsultan pajak. Sertifikat ini diperoleh dari panitia penyelenggaraan sertifikasi konsultan pajak yang diselenggarakan oleh menteri keuangan.
Terdapat tiga jenis sertifikasi konsultan pajak, pertama sertifikasi konsultan pajak tingkat A (keahlian dalam memberikan jasa bidang perpajakan kepada wajib orang pribadi), kedua sertifikasi konsultan pajak tingkat B (keahlian dalam memberikan jasa bidang perpajakan kepada wajib orang pribadi dan badan), dan terakhir sertifikasi konsultan pajak tingkat $\mathrm{C}$ (keahlian dalam memberikan jasa bidang perpajakan kepada wajib orang pribadi, badan, dan pajak internasional).

\section{Pengaruh Motivasi Ekonomi terhadap Minat Mahasiswa Akuntansi FEB di UKSW untuk Mengikuti Sertifikasi Akuntan Profesional}

Seorang mahasiswa tentunya berharap akan mendapatkan pekerjaan dengan gaji atau upah yang besar. Gaji dan jabatan seorang fresh graduate bersertifikasi dengan yang tidak tentu akan berbeda, yang bersertifikasi pasti akan lebih memiliki nilai tambah dibandingkan dengan yang tidak (Sari, 2016). Dapat disimpulkan maka, semakin tinggi motivasi ekonomi dalam diri mahasiswa akuntansi akan semakin tinggi pula minat mahasiswa untuk mengikuti sertifikasi akuntan profesional.

Hal ini juga didukung oleh penelitian Nurniah, Natsir, \& Hasan (2018), yang membuktikan bahwa terdapat pengaruh positif dan signifikan antara sertifikasi dengan gaji yang diperoleh, yang berarti sertifikasi yang diakui secara hukum juga menjadi bahan pertimbangan pemberi kerja dalam menentukan besaran gaji atau upah yang akan diberikan. Hal ini juga sejalan dengan TRA, minat perilaku seseorang didorong oleh individu itu sendiri, dalam hal ini individu akan berminat mengikuti sertifikasi akuntan profesional jika mendapatkan pengahargaan finansial atas perilaku tersebut. 
H1a: Motivasi ekonomi berpengaruh positif terhadap minat mahasiswa akuntansi FEB UKSW untuk mengikuti sertifikasi akuntan profesional.

\section{Pengaruh Motivasi Gelar terhadap Minat Mahasiswa Akuntansi FEB di UKSW untuk Mengikuti Sertifikasi Akuntan Profesional}

Gelar adalah sebuah identitas atau pengakuan mengenai keahlian seseorang dalam bidang tertentu. Semakin banyak gelar yang dimiliki, maka menunjukkan semakin berkualitas pula pendidikan seseorang (Sapitri \& Yaya, 2015). Dengan sertifikasi seseorang dapat memperoleh gelar profesional dalam bidang sertifikasi yang diikutinya. Oleh karena itu, dengan adanya motivasi untuk meraih gelar dalam diri mahasiswa akuntansi, semakin besar minat mahasiswa untuk mengikuti ujian sertifikasi akuntan profesional.

Agustina \& Yuli (2016) membuktikan bahwa motivasi gelar berpengaruh terhadap minat mahasiswa akuntansi mengikuti PPAk, yang dalam ini untuk memperoleh gelar Ak (Akuntan). Semakin tinggi gelar yang dimiliki maka semakin luas ilmu yang dimilikidan hal ini dapat mempermudah dalam mendapatkan pekerjaan, oleh karena itu motivasi gelar dapat mempengaruhi minat mengikuti sertifikasi akuntan profesional. Sejalan dengan TRA, individu melakukan suatu perilaku dalam hal ini mengikuti sertifikasi akuntan profesional, karena dorongan dari dalam mahasiswa tersebut untuk memperoleh gelar profesional dalam bidang tertentu.

H1b: Motivasi gelar berpengaruh positif terhadap minat mahasiswa akuntansi FEB UKSW untuk mengikuti sertifikasi akuntan profesional.

\section{Pengaruh Motivasi Kualitas terhadap Minat Mahasiswa Akuntansi FEB di}

\section{UKSW untuk Mengikuti Sertifikasi Akuntan Profesional}

Di era global ini, persaingan dalam dunia kerja makin ketat. Bukan hanya bersaing dengan orang-orang dengan kewarganegaraan yang sama, tetapi juga dengan orang dari negara lain. Sebagai calon akuntan, mahasiswa akuntansi harus selalu berusaha meningkatkan kemampuan profesionalnya, sertifikasi akuntan profesional bisa menjadi salah satu solusinya.

Hal ini didukung dengan penelitian Setyawan \& Iswanaji (2019) yang menyatakan motivasi kualitas berpengaruh positif terhadap minat akuntan untuk memperoleh gelar CA yang merupakan salah satu jenis sertifikasi akuntan profesional. Hal ini sesuai pula dengan teori TRA, faktor yang mempengaruhi minat perilaku adalah evaluasi seseorang terhadap perilaku tersebut. Dalam hal ini jika sertifikasi akuntan profesional dapat meningkatkan kualitas diri, maka mahasiswa akan memberikan evaluasi positif, oleh karena itu mahasiswa akan mengikuti sertifikasi akuntan profesional. Dapat disimpulkan, dengan semakin tingginya motivasi untuk meningkatkan kemampuan profesional atau bisa disebut motivasi kualitas dalam diri mahasiswa akuntansi, maka minat untuk mengikuti sertifikasi akuntan profesional akan semakin tinggi.

H1c: Motivasi kualitas berpengaruh positif terhadap minat mahasiswa akuntansi FEB UKSW untuk mengikuti sertifikasi akuntan profesional.

\section{Pengaruh Pemahaman Akuntansi terhadap Minat Mahasiswa Akuntansi FEB di UKSW untuk Mengikuti Sertifikasi Akuntan Profesional}

Seperti yang sudah dijelaskan sebelumnya, salah satu faktor internal yang mempengaruhi minat adalah pemahaman 


\section{SEGMEN Jurnal Manajemen dan Bisnis}

Volume 17 No 1 Januari 2021

p-ISSN: 0216-938X e-ISSN: 2684-8414

(Yulaini, 2018). Semakin tinggi pemahaman seseorang tentang suatu bidang, semakin tinggi pula minat orang tersebut pada bidang tersebut. Dalam hal sertifikasi akuntan profesional, pastinya dibutuhkan pemahaman mengenai akuntansi agar seseorang dapat memperoleh sertifikat tersebut. Oleh karena itu, dapat dikatakan bahwa semakin tinggi pemahaman akuntansi mahasiswa, maka semakin tinggi pula minat untuk mengikuti sertifikasi akuntan profesional. Sejalan dengan TRA seorang mahasiswa berminat mengikuti sertifikasi akuntan profesional atas dorongan individu itu sendiri dengan pertimbangan mengenai pemahaman akuntansi yang dimiliki mahasiswa itu sendiri.

Qimyatussa'adah, Kusumaningrum, \& Kirowati (2017) membuktikan bahwa salah satu faktor yang dapat mempengaruhi persepsi mahasiswa untuk memperoleh gelar sertifikasi akuntan profesional adalah materi ujian yang dianggap rumit. Terdapat 47 persen dari responden yang menganggap rumit, dan hanya 7,6 persen responden yang menganggap tidak rumit, selebihnya netral. Jika disimpulkan, seseorang yang memiliki pemahaman akuntansi tentu tidak akan menganggap rumit materi ujian sertifikasi akuntan profesional, karena sebagian besar materi yang diuji adalah bidang akuntansi. Oleh karena itu semakin luas pemahaman akuntansi seseorang, semakin tinggi pula minat untuk mengikuti sertifikasi akuntan profesional.

H2: Pemahaman Akuntansi berpengaruh positif terhadap minat mahasiswa akuntansi FEB UKSW untuk mengikuti sertifikasi akuntan profesional.

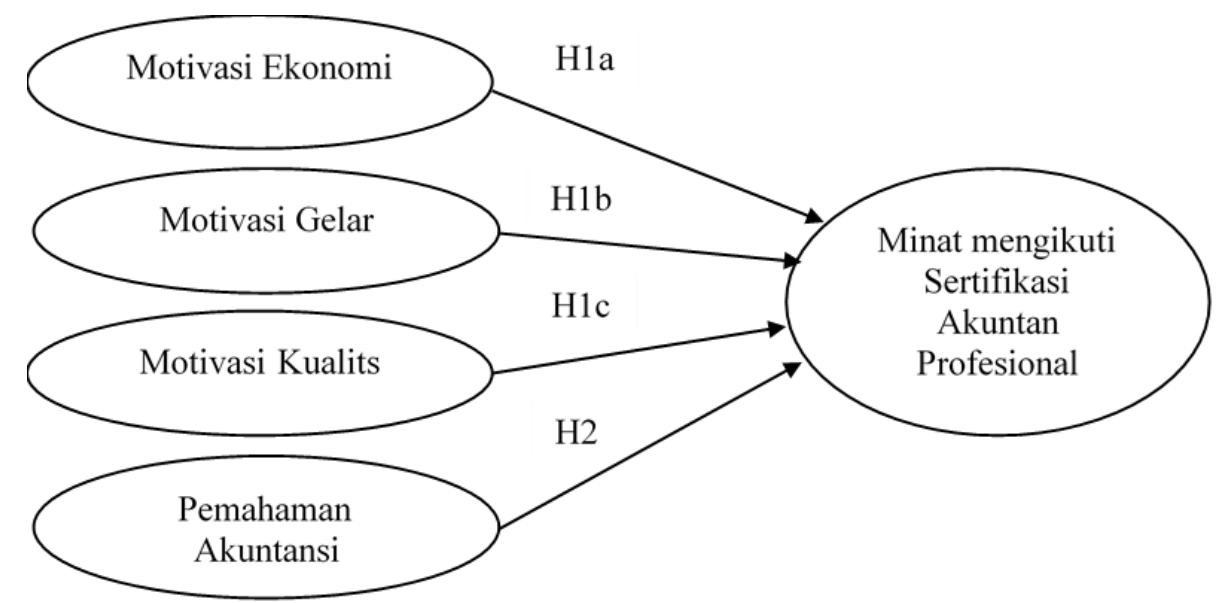

Gambar 2. Model Penelitian

Sumber: Dikembangkan untuk Penelitian (2020)

Penelitian ini dilakukan pada mahasiwa Program Studi Akuntansi di FEB UKSW, Salatiga, Jawa Tengah. Metode penelitian yang digunakan dalam penelitian ini adalah metode kuantitatif. Kuncoro (2011, 3) menyatakan metode kuantitatif merupakan suatu pendekatan ilmiah dalam pengambilan keputusan manajerial dan ekonomi. Pendekatan ini berawal dari data yang diproses dan nantinya disajikan dalam bentuk informasi yang berguna bagi pengambilan keputusan.

Jenis data dalam penelitian ini adalah data primer. Ikhsan $(2008,47)$ menjelaskan data primer sebagai data yang diperoleh langsung dari pihak pertama atau dapat dikatakan pula sumber asli. Data primer dalam penelitian ini pengumpulannya menggunakan metode survei, dengan cara memberikan pertanyaan lisan atau tertulis 


\section{SEGMEN Jurnal Manajemen dan Bisnis}

Volume 17 No 1 Januari 2021

p-ISSN: 0216-938X e-ISSN: 2684-8414

kepada responden melalui instrument kuesioner.

Populasi dalam penelitian ini adalah mahasiswa akuntansi FEB UKSW angkatan 2016 dan 2017 yang berjumlah 390 mahasiswa (BARA, 2019). Metode pengambilan sampel dalam penelitian ini adalah purposive sampling. Dengan kriteria responden, sebagai berikut:

1) Mahasiswa akuntansi aktif FEB UKSW;

2) Sudah mengambil matakuliah Pengantar Akuntansi;

3) Sudah mengambil matakuliah Akuntansi Keuangan Menengah 1;

4) Sudah mengambil matakuliah Akuntansi Keuangan Menengah 2;

5) Sudah mengambil matakuliah Akuntansi Biaya;

6) Sudah mengambil matakuliah Akuntansi Manajemen;

7) Sudah mengambil matakuliah Perpajakan;
8) Sudah mengambil matakuliah Sistem Informasi Akuntansi;

9) Sudah mengambil matakuliah Manajemen Keuangan;

10) Sudah mengambil matakuliah Teori Akuntansi;

11) Sudah mengambil matakuliah Pengauditan;

Kriteria-kriteria tersebut ditetapkan atas dasar beberapa pertimbangan, untuk kriteria responden harus mengambil mata kuliah tertentu yang sudah disebutkan di atas ditetapkan atas pertimbangan bahwa mata kuliah tersebut merupakan mata kuliah wajib atau mata kuliah Pasak Bumi Mutu (PBMt) yang harus diambil oleh mahasiswa jurusan akuntansi, sehingga seharusnya mahasiswa dapat memperoleh pemahaman mengenai akuntansi dari mata kuliah-mata kuliah tersebut.

Tabel 1

Definisi Operasional Variabel

\begin{tabular}{|c|c|c|c|}
\hline Variabel & Definisi Empiris & Indikator Empiris & Sumber \\
\hline $\begin{array}{l}\text { Motivasi } \\
\text { Ekonomi }\end{array}$ & $\begin{array}{l}\text { Motivasi ekonomi adalah } \\
\text { dorongan dalam diri seseorang } \\
\text { untuk meningkatkan kemampuan } \\
\text { pribadi dalam rangka mencapai } \\
\text { penghargaan finansial (gaji atau } \\
\text { upah). }\end{array}$ & $\begin{array}{l}\text { 1. Penghasilan (gaji } \\
\text { atau upah) yang } \\
\text { besar. } \\
\text { 2. Kesejahteraan. } \\
\text { 3. Fasilitas penunjang } \\
\text { kerja (tunjangan, } \\
\text { program pensiun) }\end{array}$ & $\begin{array}{l}\text { Sapitri \& Yaya } \\
(2015)\end{array}$ \\
\hline $\begin{array}{l}\text { Motivasi } \\
\text { Gelar }\end{array}$ & $\begin{array}{l}\text { Motivasi gelar adalah dorongan } \\
\text { dalam diri seseorang untuk } \\
\text { memperoleh gelar tertentu dalam } \\
\text { rangka meningkatkan status sosial } \\
\text { dan mempermudah mencari } \\
\text { pekerjaan. }\end{array}$ & $\begin{array}{l}\text { Memperoleh gelar } \\
\text { profesional, selain gelar } \\
\text { strata satu. }\end{array}$ & $\begin{array}{l}\text { Sari } \\
\text { al.(2017) }\end{array}$ \\
\hline $\begin{array}{l}\text { Motivasi } \\
\text { Kualitas }\end{array}$ & $\begin{array}{l}\text { Motivasi kualitas adalah dorongan } \\
\text { dalam diri seseorang untuk } \\
\text { meningkatkan kualitas diri. }\end{array}$ & $\begin{array}{l}\text { 1. Keyakinan dapat } \\
\text { bekerja dengan } \\
\text { baik. }\end{array}$ & $\begin{array}{l}\text { Setyawan \& } \\
\text { Iswanaji (2019) }\end{array}$ \\
\hline
\end{tabular}




\begin{tabular}{|c|c|c|c|}
\hline Variabel & Definisi Empiris & Indikator Empiris & Sumber \\
\hline & & $\begin{array}{l}\text { 2. Keyakinan terhadap } \\
\text { bidang yang } \\
\text { ditekuninya. }\end{array}$ & \\
\hline $\begin{array}{l}\text { Pemahaman } \\
\text { Akuntansi }\end{array}$ & $\begin{array}{l}\text { Pemahaman akuntansi adalah } \\
\text { kondisi atau keadaan saat } \\
\text { seseorang memiliki kemampuan } \\
\text { atau mengerti benar-benar suatu } \\
\text { sistem informasi keuangan } \\
\text { mengenai aktifitas ekonomi dan } \\
\text { kondisi suatu perusahaan, untuk } \\
\text { menghasilkan output berupa } \\
\text { laporan keuangan yang nantinya } \\
\text { akan digunakan sebagai dasar } \\
\text { pengambilan keputusan para } \\
\text { pemangku kepentingan dalam } \\
\text { suatu perusahaan. }\end{array}$ & $\begin{array}{l}\text { Nilai mata kuliah: } \\
\text { 1. Pengantar } \\
\text { Akuntansi } \\
\text { 2. Akuntansi } \\
\text { Keuangan } \\
\text { Menengah } 1 \\
\text { 3. Akuntansi } \\
\text { Keuangan } \\
\text { Menengah } 2 \\
\text { 4. Akuntansi Biaya } \\
\text { 5. Akuntansi } \\
\text { Manajemen; } \\
\text { 6. Perpajakan; } \\
\text { 7. Sistem Informasi } \\
\text { Akuntansi; } \\
\text { 8. Manajemen } \\
\text { Keuangan } \\
\text { 9. Teori Akuntansi } \\
\text { 10. Pengauditan }\end{array}$ & $\begin{array}{l}\text { KBBI (2019) } \\
\text { Sari \& Prastiti } \\
(2016) \\
\text { Indikator } \\
\text { Pemahaman } \\
\text { Akuntansi } \\
\text { diadopsi dari } \\
\text { penelitian } \\
\text { Suprianto \& } \\
\text { Harryoga } \\
\text { (2016) }\end{array}$ \\
\hline $\begin{array}{l}\text { Minat Untuk } \\
\text { Mengikuti } \\
\text { Sertifikasi } \\
\text { Akuntan } \\
\text { Profesional }\end{array}$ & $\begin{array}{l}\text { Keinginan dalam diri seseorang } \\
\text { untuk mengikuti prosedur } \\
\text { pemberian sertifikat kompetensi } \\
\text { sebagai bukti dirinya memiliki } \\
\text { keahlian, kemahiran, atau } \\
\text { kecakapan di bidang akuntansi } \\
\text { yang memenuhi standar mutu atau } \\
\text { norma tertentu. }\end{array}$ & $\begin{array}{l}\text { Mengikuti sertifikasi } \\
\text { akuntan profesional. }\end{array}$ & $\begin{array}{l}\text { Jogiyanto, } \\
(2007,25) \\
\text { Mulyasa } \\
(2009)\end{array}$ \\
\hline
\end{tabular}

Pada variabel independen yaitu motivasi ekonomi, motivasi gelar, dan motivasi kualitas, digunakan skala likert untuk mengukur jawaban dari responden yang berupa pernyataan sangat tidak setuju, tidak setuju, netral, setuju, dan sangat setuju. Sedangkan pada variabel independen pemahaman akuntansi juga digunakan skala likert, namun pernyataan yang digunakan adalah sangat tidak paham, tidak paham, moderat (cukup paham), paham, dan sangat paham, pernyataan tersebut diwakili oleh nilai $\mathrm{C}, \mathrm{BC}, \mathrm{B}, \mathrm{AB}$, dan $\mathrm{A}$ pada masing- masing mata kuliah yang dijadikan indikator, pengukuran ini diadopsi dari penelitian (Tjun, Setiawan, \& Setiana, 2009). Pada variabel dependen yaitu minat untuk mengikuti sertifikasi akuntan profesional digunakan skala nominal, dalam bentuk pernyataan Ya (berminat) dan Tidak (tidak berminat).

Terdapat beberapa teknik analisis data yang digunakan dalam penelitian ini, yaitu:

\section{a. Uji Validitas dan Uji Reliabilitas}

Uji validitas dan uji reliabilitas merupakan pengujian yang diperuntukan 
untuk menguji kualitas data. Uji validitas digunakan untuk menguji apakah alat ukur yang diuji benar-benar telah terukur, suatu alat ukur dikatakan valid apabila dapat mengukur apa yang seharusnya diukur. Suatu alat ukur dikatakan valid apabila hasil perbandingan $r$ tabel dengan $r$ hitung, menunjukkan bahwa $r$ hitung lebih besar dari $r$ tabel. Sedangkan uji reliabilitas digunakan untuk menguji keakuratan alat ukur (Ikhsan 2008, 209-210). Suatu alat ukur dapat dikatakan reliabel apabila cronbach alpha lebih dari 0,6.

\section{b. Uji Asumsi Klasik}

Dalam penelitian ini uji analisis klasik yang digunakan hanya uji multikolinearitas. Hal ini dikarenakan uji regesi yang digunakan adalah uji regeresi logistik biner, dalam Hayati (2016) disebutkan bahwa asumsi yang harus dipenuhi adalah ketiadaan multikolinearitas diantara variabel independent yang digunakan. Uji multikolinearitas berguna untuk menguji apakah terdapat korelasi (hubungan) antar variabel bebas (independen) dalam sebuah model regresi, hal ini dapat dilihat apabila tolerance value lebih dari 0,10 dan Variance Inflation Factor (VIF) kurang dari 10 maka variabel independen terbebas dari multikolinearitas (Dewi et al., 2018). Artha, Novia, \& Purnamasari (2016) menyatakan bahwa dalam regresi logistik biner asumsi normalitas tidak digunakan, karena regresi logistik biner digunakan apabila distribusi normal data tidak terpenuhi.

\section{c. Uji Kelayakan Model}

Uji kelayakan model regresi dilakukan untuk menilai regresi yang digunakan tersebut layak atau tidak. Uji kelayakan dapat dilihat dari uji hosmer and lemeshow dan uji rasio likelihood (overall model fit).

\section{- Uji Hosmer and Lemeshow}

Hosmer and lemeshow menguji $\mathrm{H}_{0}$ untuk mengetahui apakah model sesuai atau tidak, jika Hosmer and lemeshow memiliki nilai lebih dari 0,05 maka model layak untuk dilakukan uji regresi.

\section{- Uji Rasio Likelihood (Overall Model}

Fit)

Pada regresi logistik biner ini, digunakan uji rasio likelihood untuk menguji kelayakan model regresi secara simultan, atau dapat dikatakan untuk menguji apakah seluruh variabel independen berpengaruh terhadap variabel dependen (Azizah \& Chandra, 2017). Uji ini dilakukan dengan cara membandingkan nilai dari $\quad-2 \quad$ Log Likelihood awal (-2LL) pada blok 0 dengan nilai dari -2 Log Likelihood akhir pada blok 1. Apabila terdapat penurunan nilai likelihood, maka model regresi tersebut baik atau dapat dikatakan layak.

\section{Uji Cox and Snell Pseudo $\mathbf{R}^{\mathbf{2}}$}

Uji ini dilakukan untuk mengetahui berapa besar pengaruh variabel independen terhadap variabel dependen, dan untuk mengetahui berapa besar pengaruh dari varibel-varibel lain yang tidak dimasukan atau digunakan dalam penelitian ini (Azizah \& Chandra, 2017).

\section{ANALISIS REGRESI LOGISTIK BINER}

Menurut Gudono $(2016,177)$ analisis regresi logistik biner dilakukan untuk pembuatan model, yang varibel dependennya bersifat kategorikal (nonmetrik) atau dapat dikatakan variabel dummy, namun variabel independen dapat bersifat kontinyu (metrik) ataupun kategorikal. Rumus yang digunakan dalam penelitian ini adalah:

$\mathrm{Ln}=\alpha+\beta_{1} \mathrm{X}_{1}+\beta_{2} \mathrm{X}_{2}+\beta_{3} \mathrm{X}_{3}+\beta_{4} \mathrm{X}_{4}+\mathrm{e} .$. 
Keterangan:

Ln = Variabel Dependen Minat untuk Mengikuti Sertifikasi Akuntan

Profesional $(1=$ Ya, $0=$ Tidak $)$

$\alpha \quad=$ Konstanta Regresi

$\beta=$ Koefisien Regresi

$\mathrm{X}_{1} \quad=$ Motivasi Ekonomi

$\mathrm{X}_{2}=$ Motivasi Gelar

$\mathrm{X}_{3} \quad=$ Motivasi Kualitas

$\mathrm{X}_{4}=$ Pemahaman Akuntansi

$\mathrm{e}=$ Error Term

\section{UJI WALD}

Uji wald digunakan untuk menguji kelayakan model regresi logistik secara parsial dengan tujuan untuk menguji peran dari masing-masing variabel prediktor (independen) terhadap varibel respon

(dependen) yang digunakan. Uji wald juga dapat dikatakan digunakan untuk pengujian signifikansi atau hipotesis yang dilakukan masing-masing pada setiap parameter yang digunakan (Safitri Daruyani, Yuciana Wilandari, 2013). Signifikansi dapat dilihat dari nilai alpha apabila kurang dari nilai sig $(0,05)$ maka variabel independen yang diuji berpengaruh signifikan terhadap variabel dependen.

\section{HASIL DAN PEMBAHASAN}

Penyebaran kuesioner dalam penelitian ini dilakukan secara langsung kepada mahasiswa dan juga melalui google form yang dikirimkan ke email student mahasiswa akuntansi FEB UKSW. Distribusi kuesioner dapat dilihat melalui tabel berikut ini:

Tabel 2

Distribusi Kuesioner

\begin{tabular}{lcc}
\hline \multicolumn{1}{c}{ Keterangan } & Jumlah & Persentase \\
\hline $\begin{array}{l}\text { Kuesioner yang disebar dan } \\
\text { kembali }\end{array}$ & 200 & $100 \%$ \\
$\begin{array}{l}\text { Kuesioner yang tidak dapat } \\
\text { digunakan }\end{array}$ & 6 & $3 \%$ \\
$\begin{array}{l}\text { Kuesioner yang diolah } \\
\text { Sumber: Data Primer (2020) }\end{array}$ & 194 & $97 \%$ \\
\hline
\end{tabular}

Dari Tabel 2 diketahui bahwa kuesioner yang disebar sejumlah 200 kuesioner dan kembali sejumlah 200 kuesioner. Terdapat 6 (enam) kuesioner yang tidak dapat digunakan karena tidak memenuhi syarat responden yang telah ditetapkan, yaitu mahasiswa akuntansi aktif FEB UKSW dan sudah mengambil seluruh matakuliah Pasak Bumi Mutu (PBMt) (Pengantar Akuntansi; Akuntansi Keuangan Menengah 1; Akuntansi Keuangan Menengah 2; Akuntansi Biaya; Akuntansi
Manajemen; Perpajakan; Sistem Informasi Akuntansi; Manajemen Keuangan; Teori Akuntansi; Pengauditan). Jumlah kuesioner yang dapat digunakan adalah 194 kuesioner dari 200 kuesioner yang kembali. Hal ini menunjukkan tingkat respon yang tinggi yaitu 97 persen.

Pada bagian profil responden ini dijelaskan mengenai usia, jenis kelamin, angkatan, dan Indeks Prestasi Kumulatif (IPK) responden yang dapat dilihat pada tabel di bawah ini: 
Tabel 3

Profil Responden

\begin{tabular}{|c|c|c|c|}
\hline \multirow{2}{*}{ No } & \multirow{2}{*}{ Keterangan } & \multicolumn{2}{|c|}{ Responden } \\
\hline & & Frekuensi & Persentase \\
\hline \multirow[t]{8}{*}{1} & Usia & & \\
\hline & a. 19 tahun & 2 & $1,03 \%$ \\
\hline & b. 20 tahun & 68 & $35,05 \%$ \\
\hline & c. 21 tahun & 87 & $44,84 \%$ \\
\hline & d. 22 tahun & 31 & $15,98 \%$ \\
\hline & e. 23 tahun & 3 & $1,55 \%$ \\
\hline & f. Tidak diketahui & 3 & $1,55 \%$ \\
\hline & Total & 194 & $100 \%$ \\
\hline \multirow[t]{4}{*}{2} & Jenis Kelamin & & \\
\hline & a. Laki-laki & 46 & $23,71 \%$ \\
\hline & b. Perempuan & 148 & $76,29 \%$ \\
\hline & Total & 194 & $100 \%$ \\
\hline \multirow[t]{4}{*}{3} & Angkatan & & \\
\hline & a. 2016 & 105 & $54,12 \%$ \\
\hline & b. 2017 & 89 & $45,88 \%$ \\
\hline & Total & 194 & $100 \%$ \\
\hline \multirow[t]{8}{*}{4} & Indeks Prestasi & & \\
\hline & Kumulatif (IPK) & & \\
\hline & a. $2,00-2,74$ & 4 & $2,06 \%$ \\
\hline & b. $2,75-2,99$ & 10 & $5,15 \%$ \\
\hline & c. $3,00-3,49$ & 64 & $32,99 \%$ \\
\hline & d. $\geq 3,50$ & 111 & $57,22 \%$ \\
\hline & e. Tidak diketahui & 5 & $2,58 \%$ \\
\hline & Total & 194 & $100 \%$ \\
\hline
\end{tabular}

Berdasarkan Tabel 3, secara keseluruhan terdapat 194 responden yang merupakan mahasiswa akuntansi FEB UKSW. Mahasiswa tersebut terdiri dari 46 mahasiswa laki-laki dan 148 mahasiwa perempuan, dimana 105 mahasiwa merupakan angkatan 2016 dan 89 mahasiwa merupakan angkatan 2017. Usia mahasiswa yang menjadi responden berkisar 19 tahun sampai dengan 23 tahun. Semua mahasiswa yang menjadi responden, merupakan mahasiwa akuntansi angkatan 2016 dan 2017 dengan status aktif, serta sudah mengambil seluruh matakuliah PbMt (Pengantar Akuntansi; Akuntansi Keuangan Menengah 1; Akuntansi Keuangan Menengah 2; Akuntansi Biaya; Akuntansi Manajemen; Perpajakan; Sistem Informasi Akuntansi; Manajemen Keuangan; Teori Akuntansi; Pengauditan). Sebesar 2,06 persen mahasiswa yang menjadi responden memiliki IPK berkisar antara 2,00-2,74, 5,15 persen berkisar antara 2,75-2,99, 32,99 persen berkisar antara 3,00-3,49, dan yang terbesar 57,99 persen mahasiswa memiliki 


\section{SEGMEN Jurnal Manajemen dan Bisnis}

Volume 17 No 1 Januari 2021

p-ISSN: 0216-938X e-ISSN: 2684-8414

IPK di atas atau sama dengan 3,50, sedangkan sisanya 2,58 persen tidak diketahui IPKnya.

\section{UJI KUALITAS DATA}

Hasil uji validitas dengan menggunakan Uji pearson product moment dari variabel motivasi ekonomi, motivasi gelar, motivasi kualitas, dan pemahaman akuntansi menunjukkan bahwa seluruh item pertanyaan dalam kuesioner dinyatakan valid. Hal ini dapat dilihat dari hasil $\mathrm{R}$ hitung pada motivasi ekonomi yang berkisar antara 0,381 sampai dengan 0,778 , pada motivasi gelar yang berkisar antara 0,843 sampai dengan 0,862 , pada motivasi kualitas yang berkisar antara 0,437 sampai dengan 0,794, dan juga pada variabel pemahaman akuntansi yang berkisar antara 0,547 sampai dengan 0,748 lebih besar dari $\mathrm{R}$ tabel $(\mathrm{N}=194)$ yaitu sebesar 0,1409.

Instrument dalam penelitiaan ini juga dapat dinyatakan reliable karena berdasarkan hasil uji reliabilitas menunjukkan nilai cronbach alpha sebesar 0,821 yang berarti lebih besar dari 0,6.

\section{UJI ASUMSI KLASIK: Uji Multikolinearitas}

Dari hasil uji multikolinearitas, dapat diketahui variabel bebas motivasi ekonomi, motivasi gelar, motivasi kualitas, pemahaman akuntansi memiliki nilai VIF 1,$272 ; 1,211 ; 1,326 ; 1,083$ dan memiliki nilai tolerance 0,$786 ; 0,826 ; 0,754 ; 0,923$. Hal ini menunjukkan bahwa model regresi bebas dari multikolinearitas karena variabel dependent dalam penelitian ini memiliki nilai VIF kurang dari 10 dan nilai tolerance lebih dari 0,10 .

\section{UJI KELAYAKAN MODEL}

\section{a. Uji Hosmer and Lemeshow}

Dari hasil uji Hosmer and Lemeshow menunjukkan bahwa nilai signifikansi (sig) yaitu 0,450 lebih dari 0,05 yang berarti data dinyatakan layak dan $\mathrm{H}_{0}$ dapat diterima, sehingga dapat digunakan untuk pengujian selanjutnya.

b. Uji Rasio Likelihood (Overall Model Fit)

Hasil uji ini menunjukkan bahwa model yang digunakan dalam penelitian ini secara keseluruhan fit atau layak. Hal ini dapat dilihat dari rasio $-2 \quad \log$ Likelihood blok 0 sebesar 142,968 sedangkan rasio -2 Log Likelihood blok 1 sebesar 122,210, maka dapat disimpulkan terjadi penurunan rasio -2 Log Likelihood yang menunjukkan bahwa model regresi layak.

c. Uji Cox and Snell Pseudo $\mathbf{R}^{2}$

Tabel 4

Uji Cox and Snell Pseudo R Square

\begin{tabular}{rcc}
\hline -2 Log likelihood & Cox \& Snell R Square & Nagelkerke R Square \\
\hline 122,10 & 0,74 & 0,147 \\
\hline
\end{tabular}

Sumber: Olah Data SPSS 2020

Dari Tabel 4 di atas dapat diketahui nilai Nagelkerke R Square adalah 0,147, yang berarti bahwa variabel independen motivasi ekonomi, motivasi gelar, motivasi kualitas dan pemahaman akuntansi mempengaruhi sebesar 14,7 persen terhadap variabel dependen yaitu minat mengikuti sertifikasi akuntan profesional. Hal ini juga menunjukkan bahwa sebesar 85,3 persen variabel dependen dijelaskan oleh variabel lain diluar model penelitian ini.

Hasil Uji Hipotesis: Uji Wald 
Tabel 5

Uji Wald

\begin{tabular}{lcc}
\hline $\begin{array}{c}\text { Variabel } \\
\text { Independen }\end{array}$ & $\boldsymbol{\beta}$ & Sig \\
\hline Motivasi Ekonomi & 0,29 & 0,795 \\
Motivasi Gelar & 0,413 & 0,007 \\
Motivasi Kualitas & 0,057 & 0,544 \\
Pemahaman & 0,038 & 0,194 \\
$\quad$ Akuntansi & & \\
\hline Sumber: Data Primer Diolah (2020) &
\end{tabular}

Sumber: Data Primer Diolah (2020)

Uji hipotesis pertama menunjukkan bahwa H1a ditolak, yang berarti motivasi ekonomi tidak mempengaruhi minat mahasiswa akuntansi FEB UKSW untuk mengikuti sertifikasi akuntan profesional. Hal ini ditunjukan dengan nilai signifikansi 0,795 lebih besar dari nilai $\alpha \quad 0,05$ dan memiliki nilai koefisien positif.

Uji hipotesis kedua menunjukkan bahwa $\mathrm{H} 1 \mathrm{~b}$ diterima, yang berarti motivasi gelar mempengaruhi minat mahasiswa akuntansi FEB UKSW untuk mengikuti sertifikasi akuntan profesional. Hal ini ditunjukan dengan nilai signifikansi 0,007 lebih kecil dari nilai $\alpha 0,05$ dan memiliki nilai koefisien positif.

Uji hipotesis ketiga menunjukkan bahwa H1c ditolak, yang berarti motivasi kualitas tidak mempengaruhi minat mahasiswa akuntansi FEB UKSW untuk mengikuti sertifikasi akuntan profesional. Hal ini ditunjukan dengan nilai signifikansi 0,544 lebih besar dari nilai $\alpha 0,05$ dan memiliki nilai koefisien positif.

Uji hipotesis keempat menunjukkan bahwa H2 ditolak, yang berarti pemahaman akuntansi tidak mempengaruhi minat mahasiswa akuntansi FEB UKSW untuk mengikuti sertifikasi akuntan profesional. Hal ini ditunjukan dengan nilai signifikansi 0,194 lebih besar dari nilai $\alpha \quad 0,05$ dan memiliki nilai koefisien positif.
PEMBAHASAN

Pengaruh Motivasi Ekonomi terhadap Minat Mahasiswa Akuntansi FEB di UKSW untuk Mengikuti Sertifikasi Akuntan Profesional

Motivasi ekonomi yang merupakan dorongan dalam diri seseorang untuk meningkatkan kemampuan pribadi dalam rangka mencapai penghargaan finansial (gaji atau upah) tidak mempengaruhi minat mahasiswa untuk mengikuti sertifikasi akuntan profesional. Artinya, meskipun mahasiswa memiliki motivasi ekonomi dalam dirinya bukan berarti mahasiswa pasti akan berminat mengikuti sertifikasi akuntan profesional, begitu pun sebaliknya jika mahasiswa tidak memiliki motivasi ekonomi dalam diri bukan berarti mahasiwa tidak akan berminat mengikuti sertifikasi akuntan profesional.

Berdasarkan kuesioner penelitian yang dibagikan kepada responden, diketahui bahwa sebagian besar mahasiswa memiliki motivasi ekonomi dalam dirinya. Hal ini dilihat dari jawaban mahasiswa terhadap pernyataan mengenai motivasi ekonomi dalam kuesioner, lebih dari 90 persen mahasiswa yang menjadi responden memberikan jawaban setuju pada pernyataan mengenai motivasi ekonomi tersebut. Alasan dibalik tidak adanya pengaruh motivasi ekonomi terhadap minat mahasiswa 
mengikuti sertifikasi akuntan profesional, kemungkinan besar karena mahasiswa merasa bahwa tanpa mengikuti sertifikasi akuntan profesional pun saat bekerja nanti mahasiswa tetap dapat memperoleh pengahargaan finansial (gaji atau upah) yang mereka harapkan. Mahasiswa merasa bahwa sertifikasi akuntan profesional tidak mempengaruhi gaji atau upah yang akan mereka dapatkan saat bekerja nanti. Dapat disimpulkan bagi mahasiswa, mengikuti sertifikasi akuntan profesional tidak menjamin gaji atau upah yang akan didapatkan saat bekerja nanti akan lebih besar dibandingkan jika tidak mengikuti sertifikasi akuntan profesional. Selain itu, mahasiwa juga berpendapat bahwa sertifikasi akuntan profesional hanya akan berguna jika seseorang akan menjadi pegawai kantoran di bidang akuntansi saat bekerja nanti. Apabila tidak menjadi pegawai kantoran seperti halnya wirausahawan, maka sertifikasi akuntan profesional tidaklah diperlukan.

Temuan ini sejalan dengan penelitian Sapitri \& Yaya (2015) yang juga menyatakan bahwa motivasi ekonomi tidak berpengaruh terhadap minat mengikuti PPAk. Selain itu, penelitian Dewi et al., (2018) juga membuktikan bahwa motivasi ekonomi tidak berpengaruh terhadap minat mengikuti sertifikasi akuntan profesional.

\section{Pengaruh Motivasi Gelar terhadap Minat Mahasiswa Akuntansi FEB di UKSW untuk Mengikuti Sertifikasi Akuntan Profesional}

Motivasi gelar adalah dorongan dalam diri seseorang untuk memperoleh gelar tertentu dalam rangka meningkatkan status sosial dan mempermudah mencari pekerjaan. Berdasarkan $\mathrm{H} 1_{b}$, dengan sertifikasi seseorang dapat memperoleh gelar profesional dalam bidang sertifikasi yang diikutinya. Adanya motivasi untuk meraih gelar dalam diri mahasiswa akuntansi, mendorong minat mahasiswa untuk mengikuti ujian sertifikasi akuntan profesional. Riset ini menemukan bahwa $\mathrm{H} 1_{b}$ diterima.

Motivasi gelar berpengaruh positif terhadap minat mahasiswa akuntansi FEB UKSW untuk mengikuti sertifikasi akuntan profesional. Hal ini disebabkan oleh karena responden dalam penelitian ini merupakan mahasiswa, dimana pastinya sebagian besar mahasiswa memiliki prioritas utama untuk meraih gelar yang nantinya akan berguna bagi karir mereka dan hal ini dapat mahasiswa peroleh dengan mengikuti sertifikasi akuntan profesional. Dengan sertifikasi akuntan profesional, mahasiswa akan mendapatkan pengakuan profesional dan keahlian pada bidang sertifikasi yang diikuti, yang tentunya dapat menjadi nilai tambah bagi karir kerja mahasiswa nanti. Dari pihak pemberi kerja tentunya akan lebih mempercayai seorang mahasiswa yang bersertifikasi dibandingkan dengan yang tidak, karena dianggap memiliki wawasan dan pengetahuan yang lebih luas.

Pernyataan tersebut dapat dibuktikan dari jawaban responden atas pernyataan mengenai motivasi gelar dalam kuesioner, dimana lebih dari 70 pesen mahasiswa setuju mereka menginginkan gelar selain gelar strata satu, sedangkan sisanya sudah merasa puas dengan gelar strata satu. Penelitian ini juga membuktikan bahwa sebagian besar mahasiswa akuntansi FEB UKSW berminat mengikuti sertifikasi akuntan profesional. Hal ini dibuktikan terdapat 171 dari 194 mahasiswa yang menyatakan berminat mengikuti sertifikasi akuntan profesional. Dalam kuesioner penelitian ini juga disediakan pilihan jenis sertifikasi bagi mahasiswa yang berminat mengikuti sertifikasi, dimana mahasiswa bisa memilih 
lebih dari satu jenis sertifikasi, dan hasilnya membuktikan bahwa sebesar 73,68 persen mahasiswa memilih CPA sebagai jenis sertifikasi yang paling ingin diikuti, selain itu ada pula CA yang dipilih sebesar 50,88 persen mahasiswa, sertifikasi konsultan pajak yang dipilih 41,52 persen mahasiswa, CPMA yang dipilih 19,30 persen mahasiswa, sedangkan sebesar 2,92 persen mahasiswa memilih Sertifikasi Akuntansi Syariah (SAS), Certified Information Systems Auditor (CISA), Certified Internal Auditor(CIA), Certification in Audit Committee Practices (CACP) sebagai sertifikasi yang paling ingin diikuti.

Hasil riset ini selaras dengan Sari et al., (2017) dan Agustina \& Yuli (2016) yang membuktikan bahwa motivasi gelar berpengaruh positif terhadap minat mahasiswa mengikuti sertifikasi.

\section{Pengaruh Motivasi Kualitas terhadap} Minat Mahasiswa Akuntansi FEB di UKSW untuk Mengikuti Sertifikasi Akuntan Profesional

Meskipun dalam diri mahasiswa terdapat dorongan untuk meningkatkan kualitas dirinya atau dapat juga disebut motivasi kualitas, namun hal ini tidak mempengaruhi minat mahasiswa akuntansi FEB UKSW untuk mengikuti sertifikasi akuntan profesional. Berdasarkan kuesioner yang dibagikan kepada responden, menunjukkan bahwa lebih dari 91 persen mahasiswa yang menjadi responden merasa belum puas dengan kualitas dirinya saat ini dan selalu berusaha untuk meningkatkan kualitas dirinya, sedangkan sisanya sudah merasa puas dengan kualitas dirinya pada saat ini.

Dapat disimpulkan bahwa sebagian mahasiswa akuntansi FEB UKSW yang menjadi responden memiliki motivasi kualitas, namun hal ini bukan berarti dapat mempengaruhi minat untuk mengikuti sertifikasi akuntan profesional. Hasil penelitian ini kemungkinan besar dikarenakan oleh mahasiswa memiliki cara atau kegiatan selain sertifikasi akuntan profesional, untuk meningkatkan kualitas dirinya. Penelitian ini juga menyimpulkan bahwa mahasiswa tidak menjadikan sertifikasi akuntan profesional sebagai prioritas utama untuk meningkatkan kualitasnya. Hal ini juga dapat disebabkan oleh karena responden dalam penelitian ini adalah mahasiswa yang biasanya meningkatkan kualitas dirinya melalui kegiatan yang sebisa mungkin tidak mengeluarkan biaya besar, seperti berorganisasi atau membaca buku karena sebagian besar mahasiwa menyatakan bahwa salah satu faktor yang menghambat mereka untuk mengikuti sertifikasi akuntan profesional adalah biaya yang relatif besar.

Temuan ini tidak sejalan dengan Setyawan \& Iswanaji (2019) yang menyatakan motivasi kualitas berpengaruh positif terhadap minat akuntan untuk memperoleh gelar CA yang merupakan salah satu jenis sertifikasi akuntan profesional. Hal ini mungkin saja dikarenakan oleh perbedaan responden penelitian, dimana dalam penelitian Setyawan \& Iswanaji (2019) responden yang digunakan adalah para dosen sedangkan dalam penelitian ini yang dijadikan responden adalah mahasiswa.

Pengaruh Pemahaman Akuntansi terhadap Minat Mahasiswa Akuntansi FEB di UKSW untuk Mengikuti Sertifikasi Akuntan Profesional

Riset ini menyatakan bahwa meskipun mahasiswa semakin paham mengenai akuntansi atau memiliki pemahaman akuntansi, hal ini tidak mempengaruhi minat untuk mengikuti sertifikasi akuntan profesional. Dalam 


\section{SEGMEN Jurnal Manajemen dan Bisnis}

Volume 17 No 1 Januari 2021

p-ISSN: 0216-938X e-ISSN: 2684-8414

penelitian ini, mahasiswa yang menjadi responden memiliki pemahaman akuntansi yang dapat ditunjukan dari hasil kuesioner, dimana rata-rata hanya 3 orang mahasiswa atau 1,55 persen dari seluruh mahasiswa yang menjadi responden yang mendapatkan nilai minimal $\mathrm{C}$ atau di bawah $\mathrm{C}$ pada matakuliah PbMt.

Dapat disimpulkan, bahwa mahasiswa akuntansi FEB UKSW memiliki pemahaman akuntansi yang baik namun tidak mempengaruhi minat mengikuti sertifikasi akuntan profesional, yang berarti $\mathrm{H} 2$ dalam penelitian ini ditolak. Alasan dibalik ditolaknya $\mathrm{H} 2$ ini, kemungkinan besar karena mahasiswa menganggap sertifikasi akuntan profesional bukan sebagai tujuan atau prioritas utama mereka, sehingga meskipun mahasiswa memiliki pemahaman akuntansi yang mumpuni untuk mengikuti sertifikasi akuntan profesional tidak menjamin mahasiswa akan mengikutinya. Selain itu terdapat pula mahasiswa yang beropini bahwa mereka tidak mengikuti sertifikasi akuntan profesional karena tidak percaya diri akan kemampuan mereka dan merasa bahwa semua tes atau ujian sertifikasi akuntan profesional itu sulit. Mahasiswa tidak ingin untuk mengambil risiko, jika nanti mereka sudah mengeluarkan biaya untuk mengikuti sertifikasi akuntan profesional, namun pada kenyataannya tidak lulus atau gagal.

\section{SIMPULAN}

Hasil pengujian secara empiris penelitian ini menunjukkan bahwa hanya ada 1 (satu) variabel independen, yaitu motivasi gelar yang mempengaruhi minat mahasiswa akuntansi FEB UKSW untuk mengikuti sertifikasi akuntan profesional. Sedangkan, 3 (tiga) variabel lainnya yaitu motivasi ekonomi, motivasi kualitas, dan pemahaman akuntansi, terbukti tidak mempengaruhi minat mahasiswa untuk mengikuti sertifikasi akuntan profesional. Motivasi gelar berpengaruh terhadap minat untuk mengikuti sertifikasi akuntan profesional karena dengan sertifikasi akuntan profesional, mahasiswa dapat mencapai prioritas utama mereka untuk dapat memperoleh gelar yang nantinya akan berguna bagi karir mereka.

Selain itu ada pula alasan mengapa 3 (tiga) variabel independen yang lain tidak berpengaruh, yaitu yang pertama motivasi ekonomi tidak mempengaruhi minat mahasiswa untuk mengikuti sertifikasi akuntan profesional karena mahasiswa merasa tidak ada bedanya antara lulusan bersertifikasi dengan yang tidak di dunia kerja nanti, terutama dalam hal gaji atau upah dan juga bagi mahasiswa sertifikasi akuntan profesional hanya akan berguna bagi yang memang akan menjadi pegawai kantoran di bidang akuntansi nantinya. Untuk motivasi kualitas tidak mempengaruhi minat mahasiswa untuk mengikuti sertifikasi akuntan profesional karena mahasiswa tidak menjadikan sertifikasi akuntan profesional sebagai prioritas utama untuk tujuan meningkatkan kualitas diri. Sedangkan yang terakhir, pemahaman akuntansi tidak mempengaruhi minat mahasiswa untuk mengikuti sertifikasi akuntan profesional karena mahasiswa masih belum percaya diri dapat mengikuti tes atau ujian sertifikasi akuntan profesional yang mereka anggap sulit dan tidak berani mengambil risiko gagal dalam mengikuti sertifikasi akuntan profesional.

Penelitian ini juga menunjukan bahwa sebenarnya, sebagian besar mahasiswa akuntansi FEB UKSW berminat mengikuti sertifikasi akuntan profesional. Hal ini dibuktikan terdapat 171 dari 194 mahasiswa yang menyatakan berminat 


\section{SEGMEN Jurnal Manajemen dan Bisnis}

Volume 17 No 1 Januari 2021

p-ISSN: 0216-938X e-ISSN: 2684-8414

mengikuti sertifikasi akuntan profesional, terutama untuk jenis sertifikasi CPA. Dengan demikian, untuk kedepannya diharapkan pihak UKSW terutama FEB dapat lebih lagi mendorong dan memberikan fasilitas bagi mahasiswa akuntansi untuk mengikuti sertifikasi akuntan profesional terutama CPA, karena berdasarkan riset ini sebenarnya sebagian besar mahasiswa memiliki minat yang tinggi untuk mengikuti sertifikasi akuntan profesional.

\section{KETERBATASAN, SARAN}

Penelitian ini belum dapat menjelaskan pengaruh terhadap minat mengikuti sertifikasi akuntan profesional dengan kuat, terbukti dari nilai Nagelkerke $R$ Square yang rendah. Berdasarkan keterbatasan tersebut, terdapat saran untuk penelitian selanjutnya yaitu untuk penelitian selanjutnya diharapkan dapat menambahkan variabel lain diluar penelitian ini yang mungkin saja dapat memperkuat dalam menjelaskan pengaruh terhadap minat mengikuti sertifikasi akuntan profesional, seperti faktor-faktor eksternal, seperti contohnya social influence yang mungkin saja dapat mempengaruhi minat mengikuti sertifikasi akuntan profesional. Hal ini disarankan karena dalam penelitian ini faktor-faktor yang diteliti hanya faktor-faktor internal dari dalam diri mahasiswa saja.

\section{DAFTAR PUSTAKA}

Afrianto, D. (2016). Jumlah Akuntan Meningkat Drastis dalam 3 Tahun Terakhir. Retrieved September 27, 2019, from okezone.com website: https://economy.okezone.com/read/201 6/02/16/320/1313171/jumlah-akuntanmeningkat-drastis-dalam-3-tahunterakhir

Agustina, R., \& Yuli, J. (2016). Pengaruh Motivasi Terhadap Minat Mahasiswa
Akuntansi Di Banjarmasin Untuk Mengikuti Pendidikan Profesi Akuntansi (Studi Kasus: PTS dan PTN). Dinamika Ekonomi Jurnal Ekonomi Dan Bisnis, 9(2), 129-144.

Ajzen, I. (2005). Attitudes, Personality, And Behavior (2nd ed.; T. Manstead, Ed.). Berkshire: McGraw-Hill Professional Publishing.

Artha, C. U., Novia, Y., \& Purnamasari, I. (2016). Perbandingan hasil klasifikasi menggunakan regresi logistik dan analisis diskriminan kuadratik pada kasus pengklasifikasian jurusan di SMA Negeri 8 Samarinda tahun ajaran 2014/2015. Jurnal Eksponensial, 7(2), 179-186.

Azizah, S. M., \& Chandra, N. E. (2017). Model regresi logistik pada faktorfaktor yang mempengaruhi imunisasi lengkap balita. Jurnal Ilmiah Teknosains, 3(2), 3-6. https://doi.org/10.26877/jitek.v3i2.1882

BARA. (2019). Jumlah mahasiswa aktif FEB semester ganjil 2019/2020 angkatan 2014-2019. Salatiga.

Dewi, I. G. A. R. P., Putri, P. Y. A., \& Dewi, C. I. R. S. (2018). Niat Untuk Mengambil Sertifikasi Akuntan Dengan Pengujian Theory of Planned Behavior Dan Teori Motivasi. Jurnal Ilmiah Akuntansi, 3(2), 171-192. https://doi.org/10.23887/jia.v3i2.16639

Flora Siagian, R. E. (2015). Pengaruh Minat dan Kebiasaan Belajar Siswa terhadap Prestasi Belajar Matematika. Formatif Jurnal Ilmiah Pendidikan MIPA, 2(2), 122-131.

https://doi.org/10.30998/formatif.v2i2.9 3

Gudono. (2016). Analisis Data Multivariat

(Edisi 4). Yogyakarta: BPFEYogyakarta. 


\section{SEGMEN Jurnal Manajemen dan Bisnis}

Volume 17 No 1 Januari 2021

p-ISSN: 0216-938X e-ISSN: 2684-8414

Hayati, E. (2016). Perbandingan analisis diskriminan linear, regresi logistik biner dan Radial Basis Function Neural Network (RBFNN) (studi kasus pada pengklasifikasian ketepatan waktu penyampaian laporan keuangan perusahaan manufaktur di BEI). Jurnal Akuntansi, $\quad 1(1), \quad 10$. https://doi.org/10.30736/jpensi.v1i1.12

IAI. (2016). Kejar Ketertinggalan Akuntan di ASEAN IAI Siapkan Sertifikasi dan Penataan Profesi. Retrieved September 28, 2019, from iaiglobal.or.id website: http://www.iaiglobal.or.id/v03/beritakegiatan/detailberita-895=siaran-pers-iai-icaew-seminar-\#

Ikatan Akuntan Publik Indonesia. (2016). Informasi sertifikasi. Retrieved Oktober 28, 2019, from iapi.or.id website: https://iapi.or.id/Iapi/certifications/certi fication_info

Ikhsan, A. (2008). Metode Penelitian Akuntansi Keperilakuan (Edisi 1). Yogyakarta: Graha Ilmu.

Jogiyanto. (2007). Sistem Informasi Keperilakuan (Edisi 1). Yogyakarta: CV. Andi Offset.

Kuncoro, M. (2011). Metode Kuantitatif (Edisi 4). Yogyakarta: Unit Penerbit dan Percetakan.

Lukman, A., Rasuli, M., \& Susanti, S. (2015). Faktor-faktor yang Mempengaruhi Minat Mahasiswa Akuntansi untuk Mengikuti Pendidikan Profesi Akuntansi (PPAk) pada Perguruan Tinggi di Pekanbaru. Jurnal Online Mahasiswa Fakultas Ekonomi Universitas Riau, 2(1).

Mihartinah, D., \& Coryanata, I. (2018). Pengaruh Sikap Terhadap Perilaku, Norma Subjektif, Dan Kontrol Perilaku Persepsian Terhadap Niat Mahasiswa Akuntansi Untuk Mengambil Sertifikasi
Chartered Accountant Jurnal Akuntansi, $8(2)$, $77-88$. https://doi.org/10.33369/j.akuntansi.8.2. 77-88

Mulyasa. (2009a). Standar kompetensi dan sertifikasi guru (Edisi 1; Mukhlis, Ed.). Bandung: PT Remaja Rosdakarya.

Mulyasa. (2009b). Standar Kompetensi dan Sertifikasi Guru (Edisi 1; Mukhlis, Ed.). Bandung: PT Remaja Rosdakarya.

Nisa, N. A. K. (2012). Faktor-Faktor Yang Mempengaruhi Minat Mahasiswa Untuk Mengikuti Program Pendidikan Profesi Akuntansi. Universitas Muhamadiah Surakarta.

Nurniah, Natsir, S., \& Hasan, D. (2018). Analisis Manfaat Sertifikat Kompetensi Terhadap Peluang Kerja Alumni Jurusan Akuntansi Politeknik Negeri Ujung Padang. Prosiding Seminar Hasil Penelitian (SNP2M), 149-154.

Qimyatussa'adah, Kusumaningrum, D., \& Kirowati， D. (2017). Faktor-Faktor Yang Mempengaruhi Persepsi Mahasiswa Jurusan Akuntansi Untuk Memperoleh Gelar Sertifikasi Profesional Akuntansi. Jurnal AKSI (Akuntansi Dan Sistem Informasi), 1(2), 56-64.

https://doi.org/10.32486/aksi.v1i2.118

Sadirman. (1986). Interaksi dan Motivasi Belajar Mengajar (Edisi 1). Jakarta: CV. Rajawali.

Safitri Daruyani, Yuciana Wilandari, H. Y. (2013). Faktor-faktor yang mempengaruhi indeks prestasi mahasiswa FSM Universitas Diponegoro semaster pertama dengan motode regresi logistik biner. Prosiding Seminar Nasional Statistika, 185-193.

Sapitri, Z., \& Yaya, R. (2015). Faktor-Faktor Yang Berpengaruh Terhadap Minat Mahasiswa Untuk Mengikuti 
Pendidikan Profesi Akuntansi (PPAk). Jurnal Akuntansi \& Investasi, 16(1), 4661.

Sari, D. F., \& Prastiti, S. D. (2016). Pengaruh Kecerdasan Interpersonal Terhadap Pemahaman Akuntansi Dengan Kepercayaan Diri Sebagai Variabel Intervening Pada Siswa Jurusan Akuntansi. Journal of Accounting and Business Education, 1(2).

Sari, M. P. (2016). Ikuti Sertifikasi Profesional Ini, Nilai Jual Profesi Akuntan Bertambah. Retrieved October 6, 2019, from kompasiana.com website: https://www.kompasiana.com/muthiaps /5752edb1c1afbd4d0aa9f15d/ikutisertifikasi-profesional-ini-nilai-jualprofesi-akuntan-bertambah?page $=$ all

Sari, S. K., Andini, R., \& Paramita, P. D. (2017). Faktor-Faktor Yang Mempengaruhi Minat Mahasiswa Akuntansi Untuk Mengikuti Pendidikan Profesi Akuntansi (PPAk). Journal of Accounting, 3(3).

Setyawan, S., \& Iswanaji, C. (2019). Pengaruh Motivasi Akuntan Terhadap Minat untuk Memperoleh Gelar Chartered Accountant (CA) di Wilayah Yogjakarta. Jurnal Riset Akuntansi Dan Keuangan, 7(2), 127-142.

Sidik, S. (2019). Sri Mulyani ke Lulusan STAN: Harus Lebih Hebat dari Robot! Retrieved September 27, 2019, from cnbcindonesia.com website: https://www.cnbcindonesia.com/tech/2 0190919104333-37-100590/srimulyani-ke-lulusan-stan-harus-lebihhebat-dari-robot

Suprianto, E., \& Harryoga, S. (2016). Faktorfaktor penentu tingkat pemahaman akuntansi. Jurnal Ekonomi Dan Bisnis, 18(3), 75.
Tjun, L. T., Setiawan, S., \& Setiana, S. (2009). Pengaruh Kecerdasan Emosional Terhadap Pemahaman Akuntansi Dilihat dari Perspektif Gender. Jurnal Akuntansi, 1(2), 101118.

Undang-undang Republik Indonesia nomor 14 tahun 2005 pasal 1 ayat 4 tentang Guru dan Dosen. Lembaran Negara Republik Indonesia Tahun 2005 Nomor 14. , (2005).

Uno, H. B. (2012). Teori Motivasi \& Pengukurannya (1st ed.). Jakarta: PT Bumi Aksara.

Yulaini, E. (2018). Hubungan Pemahaman Profesi Kependidikan Dengan Minat Menjadi Guru Mahasiswa Pendidikan Akuntansi Universitas PGRI Palembang. Jurnal Ilmiah Kependidikan, 5(1), 59-70. https://doi.org/10.24914/jeb.v18i3.281 